\title{
Toward a minimal model of a large spiking cell
}

\author{
Anthony R Kellems, Steven J Cox \\ From Nineteenth Annual Computational Neuroscience Meeting: CNS*2010 \\ San Antonio, TX, USA. 24-30 July 2010
}

Experimentalists will soon be able to ascertain the highly nonuniform morphology and channel distributions of the large, pyramidal cells that populate the mammalian cortex. This advance is captured and quantified via tens of thousands of coupled nonlinear ordinary differential equations, per cell. The circuit modeler then asks, "How many of these equations must I keep in order to guarantee a fixed level of accuracy in the input-output map?" We demonstrate that the combined application of Balanced Truncation [1] to the weakly excitable portion of the tree and Principal Orthogonal Decomposition and the Discrete Empirical Interpolation Method [2] to the strongly excitable portion of the cell permit one to reduce the system size by more than one order of magnitude and decrease simulation time by a factor of 5 without sacrificing synaptic specificity in space or time.

Acknowledgements

NIBIB Grant No. 1T32EB006350-01A1

Published: 20 July 2010

\section{References}

1. Kellems AR, Roos D, Xiao N, Cox SJ: Low-dimensional, morphologically accurate models of subthreshold membrane potential. J Comput Neurosci 2009, 27:161-176.

2. Kellems AR, Chaturantabut S, Sorensen DC, Cox SJ: Morphologically accurate reduced order modeling of spiking neurons,. TRO9-12, CAAM, Rice U 2009 [http://www.caam.rice.edu/tech_reports/2009/TR09-12.pdf].

Submit your next manuscript to BioMed Central and take full advantage of:

- Convenient online submission

- Thorough peer review

- No space constraints or color figure charges

- Immediate publication on acceptance

- Inclusion in PubMed, CAS, Scopus and Google Scholar

- Research which is freely available for redistribution

Submit your manuscript at www.biomedcentral.com/submit
Department of Computational \& Applied Mathematics, Rice University, Houston, TX, 77005, USA 